\title{
Comparison of Learning Outcomes Using Concept Map Media and Audio- Visual Media Developed in The R\&D Model in Education Statistics Courses in Odd Semester 2019 Classes of Biology Study Programs
}

\author{
Pandu Prabowo Warsodirejo $0^{1, a *}, \&$ Budianto $^{1, b}$ \\ 1Faculty of Teachers Training and Education, North Sumatera Islamic University, Medan, 20217, Indonesia \\ a panduprabowo@fkip.uisu.ac.id; b budianto@fkip.uisu.ac.id \\ *Corresponding Author : panduprabowo@fkip.uisu.ac.id | Phone : +6282277180617, +6281271579499
}

\begin{abstract}
This study aims to determine whether there are significant differences between student learning outcomes using media concept maps and Audio-Visual media on educational statistics material in the Biology Education Study Program by teaching using concept map media and Audiovisual media. This type of research is experimental research. The sample in this study was only 1 class, 32 students. Sampling was done by purposive sampling. The results of this study indicate that student learning outcomes use audio-visual media rather than teaching using concept maps, where obtained $X 1=7.806$ and SD $X 1=0.788$ for Audiovisual Media, while for conventional teaching obtained $X 2=6.333$ and SD $X 2=2.224$ While the percentage the increase in student learning outcomes of the experimental class was $35.12 \%$ and the percentage of the control class increased by $32.20 \%$. The results of data analysis showed $t$ hit $>t$ table $(5.43>2.00)$. So it can be concluded that there is an influence of the use of audio-visual media on learning outcomes in biology statistical material for the fourth semester of the Biology Education Study Program
\end{abstract}

Keywords: Statistics Learning outcomes; Concept Map Media; Audio Visual Media; Research and Development;

\section{Introduction}

Education in Indonesia at this time can still be seen being covered by major problems, including: 1). The quality of education assessed is still low, 2). Inadequate learning system and 3). The moral crisis that still engulfs Indonesian society (Ginting, 2006). The development of education in modern times like today requires students to study harder. Whether or not the quality of education can be seen from the learning achievements of children ranging from basic education to higher education. The government has made various efforts to improve the quality of education, one of which is improving educational facilities and infrastructure. Whether or not the learning achievement obtained by students can be influenced by several factors, one of which is the learning media factor which is used to increase student interest and learning interest and clarify the subject matter given at school.

The use of learning media is an element that strongly supports the improvement of student learning achievement at school, said so because so far students always learn in what they are using the simple media they receive in class. Students will be bored and tired of receiving lessons if from day to day using the same media, they will only fantasize and wished - or tell stories when looking at a whiteboard decorated with chalk and the teacher who raved in front of them, especially students who sit in the back seat, they will tell stories back when the teacher explains on the board because they are not interested in the lesson. For this reason, it is necessary to find a solution to make them become interested and excited when the lesson is given (Ginting, 2006). It is the system and facilities and infrastructure that are lacking that make students bored and bored, so that education in Indonesia is getting worse. Director General of Higher Education Satryo Soemantri Brodjonegoro in a joint meeting with the Indonesian Student Association (PPI) in Paris also acknowledged that the position of Education in Indonesia was still lacking in the Asian region. According to Satryo, Indonesia's education has led to an ideal position at the world level, also the position in Asia is quite competitive, but the conditions are not optimal, there are still many infrastructures, facilities and infrastructure that have not been addressed. The assessment is the result of a UNESCO Agency survey. It was said by UNESCO the quality of Indonesian education in Asia was still lacking, although it had 
improved from 2001 to 2008. From 193 UNESCO member countries, the position of the quality of Indonesian education was at the middle and upper levels. This is an indicator that various efforts are still needed to improve the quality of education. One component that determines the learning process is the teacher and the teaching strategies used. Teachers also play a role in efforts to form potential human resources. Therefore the teacher plays an active role in placing a position as a professional staff in accordance with the demands of an increasingly growing society. Teachers must always use all efforts, including using the skills they have, one of those skills is the use of media in learning while teaching. Another thing that teachers need to pay attention to is the global challenges of computer technology, the future challenges faced by teachers are getting heavier, teachers will also be left behind if they are unable to adapt to the modern era like today. If the student is smarter than the teacher, the teacher himself will feel ashamed, isn't it something to be proud of because the student is smart and masters technology and the teacher is indifferent, but this is an indicator that shows that the teacher is still lagging behind his own student. In an effort to improve the quality of education, the teacher inevitably has to study again, must change. There are still many teachers lacking in the mastery of Computer Science and Technology, as in the Analytical Daily edition Wednesday, July 22, 2009: 20-22 it was told that the results of the Karya Tulis Ilmiah/KTI (Scientific Writing) organized by the Provincial LPMP (Institute for Educational Quality Assurance) in various regions of Indonesia turned out not as easy and as beautiful as imagined.

The first trial results show that many teachers are still reluctant to follow the learning process by computer and the internet for various reasons, the most dominant being the inability to operate a computer let alone the internet. Ironic, but that is reality on the ground. Therefore, to support the development of educational quality, teachers must be able to utilize educational technology. As computer technology has the most potential to be a mainstay weapon for teachers in the learning process, namely as a learning medium. If the teacher has been able to master computer technology as expected, then it is certain that the quality of education in Indonesia will certainly advance and develop. Many Schools have adopted the use of media in the Teaching and Learning Process. However, the use of such media is only limited to simple media such as the use of Charta, Image Media or simple schemes such as Concept Maps and the use of such media is only limited if necessary according to the needs of the learning process such as only during discussion activities or in group work. As the author's own experience when implementing PPL, when teaching using simple visual media such as concept maps, the results are still unsatisfactory, because there are also students who do not pay attention when the authors teach in front of the class by using concept map media. When the material test was conducted using the concept map media, the results were still unsatisfactory because there were still some students whose test results were below average.

\section{Methods}

\subsection{Research Location, Materials and Tools}

This study was conducted in the fourth semester class of Biology Education Study Program Semester IV. The study period is 6 months or 1 semester from February to July 2019.

\subsection{Population and Sample}

The population in this study were 3 classes, namely Semester IV, V, and VI of the Biology Education Study Program. The sample in this study there are 1 semester semester IV Biology Education Study Program and 2 classes namely semester V and VI classes as a sample of media development with a total is 30 students.

\section{Research Design, Work Procedure,and Observation}

\section{Research Design}

This research was conducted in the Biology Education Study Program Class IV. This research is a quasi experimental study. The steps used in this study are as follows: a) Preparation Phase, including: 1) Arranging the research schedule; 2) Making the Design of Teaching Programs; 3) Set questions as a data collection tool. b) Implementation Phase, including: 1) Determining the sample class of the existing population; 1) Carry out the teaching and learning process; 3) Give the final test.

The procedure of this research was carried out in three stages, namely: 1) First Stage: Providing an initial ability test (pre-test) with an objective test form; 2) Provide teaching using the concept map media in class XI IPA-7 and in class XI IPA-8 by applying the use of audio-visual media; and 3) Give the final test in the form of objective tests to students who have done good learning by applying concept maps and by using audio-visual media.

To analyze data in testing hypotheses from experiments using the experimental class and the control class, the following formula is used:

$\mathrm{T}=(\mathrm{Xa}-\mathrm{Xb}) /($ combination S $) \times 1 / \mathrm{n} 1+1 / \mathrm{n} 2(\mathrm{SQRT})$

Where the combination S2 $=((\mathrm{n} 1-1)$ S1 multiplies $+(\mathrm{n} 2-1) \mathrm{S} 2$ multiplies $) / \mathrm{n} 1+\mathrm{n} 2-2$ 
ttable by testing one party, that is the right party: $\mathrm{dk}=\mathrm{n} 1+\mathrm{n} 2-2$. With the testing criteria, namely: $\mathrm{t}_{\text {count }}$ $>t_{\text {table, }}$ and $\mathrm{H} 0$ is rejected.

Media Concept maps and Audio Visual Media are designed using the RnD (Research and Development) model, which is a development model using 3D.

The concept map media and Audio Visual Media that are used are also made by conducting trials to upper semester students where they have already gone through the statistical lecture process.

\section{Results and Discussions}

\section{Results}

Validity Test

Test results are said to be valid if after being calculated using the product moment correlation formula, the value of $r$ count $>r$ table is obtained. From the results of the validity test tested on 40 students with 40 respondents, 35 valid questions were obtained from 40 items that were tested. These questions can be seen in appendix 4 page 86. In 5 invalid questions were corrected by replacing the questions and retested so that all 40 questions could be used as research instruments.

Test Reliability

The problem is said to be reliable if after calculated using the Kuder and Richardson formula (KR20) the $r$ count $>r$ table is obtained. From the calculation of the reliability test in the appendix, it was found that from 35 questions that had been valid, the problems were said to be reliable namely 0.7669 , so that they could be used to measure student learning outcomes.

Table 1. Data table results of Media Development Questionnaires

\begin{tabular}{|c|c|c|c|c|c|c|c|c|c|c|c|c|c|}
\hline \multirow{3}{*}{ No. } & \multirow{3}{*}{ Semester } & \multicolumn{10}{|c|}{ Aspects } & \multirow{3}{*}{ Total } & \multirow{3}{*}{$x$} \\
\hline & & \multicolumn{3}{|c|}{$\begin{array}{c}\text { Effects of Learning } \\
\text { Strategies }\end{array}$} & \multicolumn{3}{|c|}{ Communication } & \multicolumn{4}{|c|}{ Technical Design } & & \\
\hline & & 1 & 2 & 3 & 1 & 2 & 3 & 1 & 2 & 3 & 4 & & \\
\hline 1 & IV & 4 & 4 & 4 & 4 & 4 & 4 & 4 & 3 & 4 & 3 & 38 & 3.8 \\
\hline 2 & IV & 3 & 4 & 4 & 4 & 4 & 4 & 3 & 4 & 4 & 4 & 38 & 3.8 \\
\hline 3 & IV & 3 & 4 & 4 & 4 & 3 & 4 & 3 & 4 & 4 & 4 & 37 & 3.7 \\
\hline 4 & IV & 3 & 4 & 3 & 4 & 3 & 3 & 3 & 2 & 3 & 3 & 31 & 3.1 \\
\hline 5 & IV & 3 & 3 & 2 & 2 & 3 & 2 & 3 & 2 & 3 & 3 & 26 & 2.6 \\
\hline 6 & IV & 3 & 2 & 2 & 2 & 3 & 3 & 4 & 2 & 3 & 3 & 27 & 2.7 \\
\hline 7 & IV & 4 & 3 & 3 & 2 & 4 & 4 & 4 & 2 & 3 & 4 & 33 & 3.3 \\
\hline 8 & IV & 4 & 2 & 3 & 2 & 3 & 3 & 4 & 3 & 4 & 4 & 32 & 3.2 \\
\hline 9 & IV & 3 & 3 & 3 & 2 & 3 & 4 & 4 & 3 & 3 & 3 & 31 & 3.1 \\
\hline 10 & IV & 3 & 2 & 4 & 2 & 3 & 3 & 4 & 3 & 3 & 3 & 30 & 3 \\
\hline 11 & IV & 4 & 3 & 4 & 4 & 3 & 4 & 4 & 4 & 3 & 3 & 36 & 3.6 \\
\hline 12 & IV & 3 & 2 & 4 & 4 & 3 & 3 & 4 & 4 & 3 & 4 & 34 & 3.4 \\
\hline 13 & IV & 3 & 3 & 4 & 4 & 3 & 4 & 3 & 4 & 3 & 4 & 35 & 3.5 \\
\hline 14 & IV & 3 & 2 & 4 & 4 & 3 & 3 & 3 & 4 & 3 & 3 & 32 & 3.2 \\
\hline 15 & IV & 3 & 4 & 4 & 4 & 4 & 2 & 3 & 4 & 3 & 3 & 34 & 3.4 \\
\hline 16 & IV & 3 & 4 & 4 & 3 & 4 & 3 & 3 & 4 & 4 & 3 & 35 & 3.5 \\
\hline 17 & IV & 3 & 4 & 4 & 3 & 4 & 4 & 3 & 4 & 4 & 3 & 36 & 3.6 \\
\hline 18 & IV & 3 & 4 & 4 & 3 & 4 & 4 & 3 & 4 & 4 & 3 & 36 & 3.6 \\
\hline 19 & IV & 3 & 4 & 3 & 3 & 4 & 3 & 3 & 4 & 4 & 3 & 34 & 3.4 \\
\hline 20 & IV & 4 & 3 & 4 & 4 & 3 & 4 & 4 & 3 & 3 & 2 & 34 & 3.4 \\
\hline 21 & $\mathrm{~V}$ & 3 & 3 & 4 & 4 & 3 & 4 & 4 & 3 & 3 & 3 & 34 & 3.4 \\
\hline 22 & $\mathrm{~V}$ & 4 & 3 & 4 & 4 & 3 & 4 & 4 & 3 & 4 & 2 & 35 & 3.5 \\
\hline
\end{tabular}


International Journal for Educational and Vocational Studies, 2 (9) (2020), 806-812

\begin{tabular}{ccccccccccccccc}
\hline 23 & $\mathrm{~V}$ & 4 & 3 & 4 & 3 & 3 & 4 & 3 & 3 & 4 & 3 & 34 & 3.4 \\
\hline 24 & $\mathrm{~V}$ & 2 & 4 & 3 & 4 & 4 & 4 & 3 & 4 & 2 & 2 & 32 & 3.2 \\
\hline 25 & $\mathrm{~V}$ & 3 & 4 & 3 & 4 & 4 & 3 & 4 & 4 & 3 & 3 & 35 & 3.5 \\
\hline 26 & $\mathrm{~V}$ & 2 & 3 & 3 & 4 & 3 & 3 & 4 & 4 & 2 & 4 & 32 & 3.2 \\
\hline 27 & $\mathrm{~V}$ & 3 & 4 & 3 & 4 & 3 & 3 & 4 & 4 & 3 & 4 & 35 & 3.5 \\
\hline 28 & $\mathrm{~V}$ & 3 & 4 & 3 & 4 & 3 & 3 & 4 & 4 & 2 & 3 & 33 & 3.3 \\
\hline 29 & $\mathrm{~V}$ & 4 & 4 & 4 & 4 & 3 & 4 & 4 & 4 & 3 & 4 & 38 & 3.8 \\
\hline 30 & $\mathrm{~V}$ & 4 & 4 & 4 & 4 & 4 & 4 & 4 & 4 & 4 & 3 & 39 & 3.9 \\
\hline & Total & 97 & 100 & 106 & 103 & 101 & 104 & 107 & 104 & 98 & 96 & 1016 & 101.6 \\
\hline
\end{tabular}

Table 3. Student Assesment

\begin{tabular}{|c|c|c|}
\hline No. & Aspects & (\% Eligibility) \\
\hline 1 & Effect of Learning Strategies & 84.17 \\
\hline 2 & Communication & 85.56 \\
\hline \multirow[t]{2}{*}{3} & Technical design & 84.38 \\
\hline & Total Aspect & 85 \\
\hline
\end{tabular}

Table 4. Student Assesment Second Stage

\begin{tabular}{|c|c|c|}
\hline No. & Aspects & (\% Eligibility) \\
\hline 1 & Increase Knowledge & 80.83 \\
\hline 2 & Ease of use & 83.33 \\
\hline 3 & Increase motivation & 88.33 \\
\hline 4 & Ease of understanding video & 85.83 \\
\hline 5 & Clarity of use instructions & 84.17 \\
\hline 6 & Use of language & 84.17 \\
\hline 7 & Use of letters & 86.67 \\
\hline 8 & Use of color & 89.17 \\
\hline 9 & Giving illustrations & 86.67 \\
\hline \multirow[t]{2}{*}{10} & Sound use & 81.67 \\
\hline & Total Aspects & 85.08333333 \\
\hline
\end{tabular}

\section{Discussion}

Research Hypothesis

The hypotheses in this study are:

Ho: Student learning outcomes for statistics taught using audio-visual media are smaller or equal to statistical learning outcomes using concept map media for students of Biology education study program FKIP UISU.

Ha: Student statistical learning outcomes taught using audio-visual media are greater than statistical results of students taught using concept maps on statistical material in students of the biology education program FKIP UISU.

After knowing that both sample classes are normally distributed and have the same variant (homogeneous), then hypothesis testing can be done using the statistical test $t$. In the post-test hypothesis test 
data obtained tcount $=5.43$ at the real level $\alpha=0.05$ and $d k=78$ with $t(0.975)(78)=2.006$. Test criteria are to accept Ho if $t$ table and reject Ho if $t$ has another price. From the calculation, tcount $=5.43>2.006$. This means that Ho was rejected while Ha was accepted so that it was concluded "Student statistics learning outcomes taught using the concept map media are greater than statistical learning outcomes of students who are taught using concept maps media on statistics lectures on biology education study programs in FKIP UISU

Description of student learning outcomes after receiving treatment are: for groups of students taught using audio-visual media on statistical material obtained an average value $=7.51$, standard deviation $=$ 0.888 , lowest value $($ minimum $)=4.5$ highest value $($ maximum $)=8.75$ while for the group of students who were taught using the concept map media on statistical material, the average value obtained $=5.92$ standard deviations $=1,511$ lowest $($ minimum $)=3.5$ highest value $($ maximum $)=8.75$. After testing the hypothesis of a one-sided post-test, namely the right hand side, the $t$-count $=5.43$ while the $t$-count $=2.00$. Test criteria are accepted Ho if $t \leqslant t$ table and reject Ho if $t$ has another price. From the calculation, tcount $=5.43>2.00$. This means that Ho was rejected while Ha was accepted so that it was concluded "Student learning outcomes statistics taught using audio-visual media are greater than statistical learning outcomes taught using concept map media on statistical material of students in Biology education study programs. From the calculation of $\%$ increase in learning outcomes, it is known that the magnitude of the increase in learning outcomes for the Experimental class is $33.96 \%$ higher than the control class of $30.20 \%$ This shows that the use of audio visual media is very influential in improving student biology learning outcomes because it is considered more effective and interesting and makes it easier for students to understand statistical material.

\section{Test Difficulty Level}

The criteria for a good question instrument are, having the following distribution of questions $25 \%$ easy, $50 \%$ moderate, $25 \%$ difficult. From the calculations in the appendix listed in table the level of difficulty test, it was found that the level of difficulty level was $0.2-0.93$. With the distribution of $31.4 \%$ easy questions, $54.3 \%$ medium questions and $14.3 \%$ difficult questions.

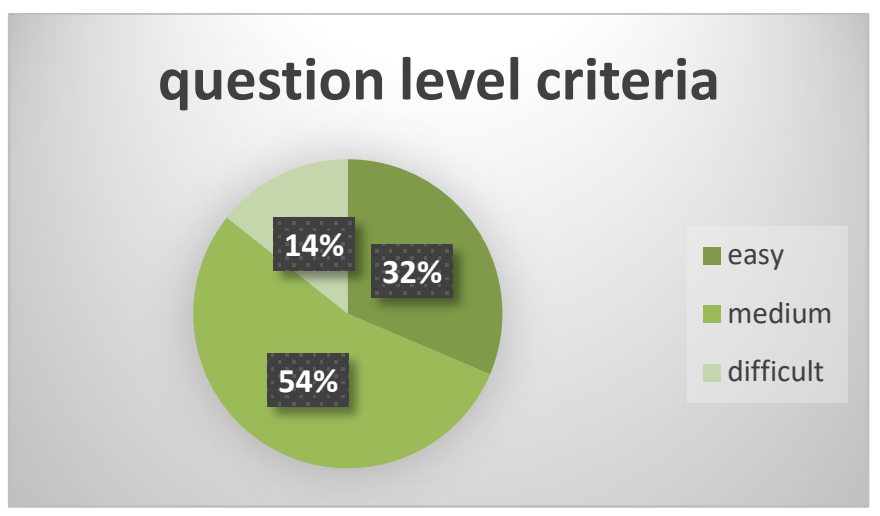

Figure 1. Question Level Criteria

Distinguishing Power of the Problem

The criteria for a good question instrument is if there are no bad question criteria out of all the test instruments. However, in this study 34 questions were still found that had poor criteria. The value of the different power problems obtained in Appendix 12 listed in table 7 is $0.1-0.45$. The questions tested have a distinguishing power with a good distribution of $11.4 \%, 77.2 \%$ is sufficient and, $11.4 \%$ is bad.

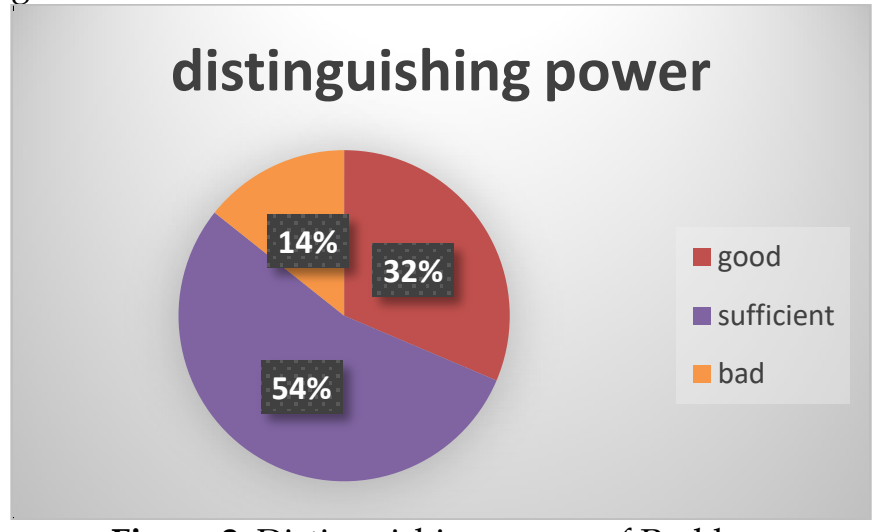

Figure 2. Distinguishing power of Problem 


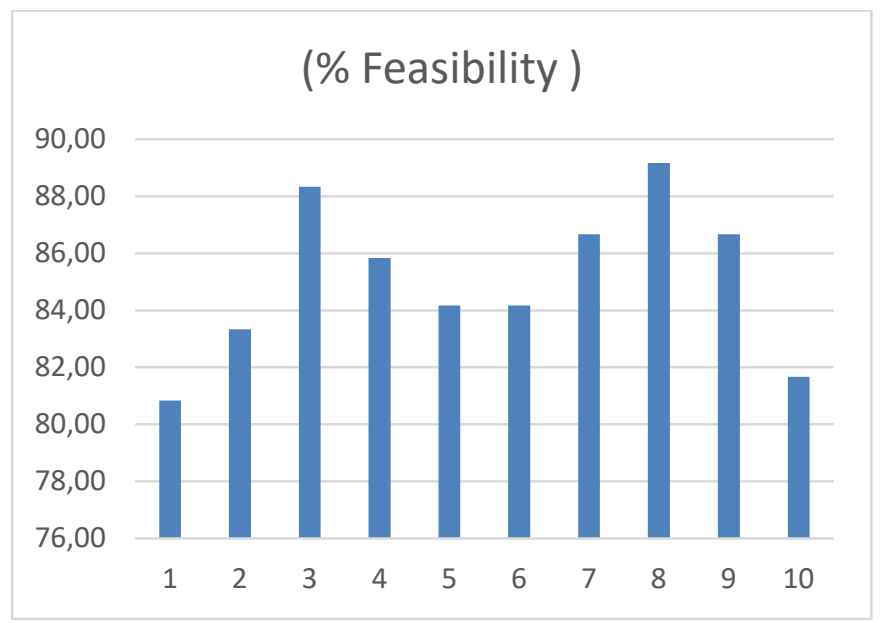

Figure 3. Students assessment Second Stage

Based on the analysis of research instrument data, from 35 valid questions it was found out the level of difficulty of the questions obtained was $31.4 \%$ easy, $54.3 \%$ moderate, and $14.3 \%$ difficult. As for the power of different problems, $11.4 \%$ of the questions were categorized as good, $77.2 \%$ of the questions were categorized as sufficient, and $11.4 \%$ of the questions were categorized as poor. After the research instrument data has been analyzed, it is known that the research instrument used has a good category, then a pre-test is conducted which aims to determine the students' initial abilities before the material is taught. Based on the results of data processing in the study it has been obtained the average value of the experimental class for pre-test 3.1 while the pre-test for control class 2.9. After the data is analyzed. So both of these classes meet the requirements because both are normally distributed and have the same variance (homogeneous).

After both of them meet the requirements of normal and homogeneous distribution, both classes can be given teaching treatment. For the experimental class teaching is given using computer-based mutimedian and for the control class given teaching without computer-based multimedia. After treatment was given, the results of the post-test study found that the average post-test of the experimental class was 7.51 while the post-test average for the control class was 5.92, which meant that the average value of the experimental class was higher than the average value of the experimental class. control class. If you look at the table, then you can see the frequency of the number of experimental class students who have a value above completeness (above 6) more than 38 people, while the frequency of the number of students in the control class who have values above completeness (above 6) ) a number of 17 people. This is due to differences in teaching media used in the learning process. As we know, teaching in the experimental class uses audio-visual media, so students are able to understand the material more clearly, also can answer the post-test questions that are given correctly. While in the teaching control class is done using the concept map media so that students experience limitations and are less interested in understanding the material being taught.

\section{Conclusion}

From the Based on the data analysis that has been done, the following conclusions can be drawn:

1. The average value of learning outcomes of control class students who were taught using the concept map media was 5.92 with a standard deviation of 1.511 .

2. The average value of student learning outcomes in the Experiment class taught using Audio-visual media that is equal to 7.51 with a standard deviation of 0.888 .

3. Obtained results namely the average value of student learning outcomes in the Experiment class is 7.51 while the Control is 5.92 it can be concluded the average value of the experimental class is higher than the average value of the control class. The percentage increase in student learning outcomes of the experimental class taught using audio-visual media is higher, that is equal to $33.96 \%$ while the percentage increase in the learning outcomes of the control class is $30.20 \%$.

\section{Suggestion}

Suggestions that can be made after conducting this research are:

1. It is hoped that lecturers, especially lecturers in the field of biology education studies in statistical subjects, will be better able to utilize learning media.

2. It is hoped that the study program will conduct training on the use of computer-based audio-visual media for lecturers, so that it can be utilized in the lecture process to be more effective. 


\section{References}

Ali, M., (2005), Educational Research Procedures and Strategies, Angkasa Publisher, Bandung Arsyad, A, (2007), Learning Media, Publisher Pt. Raja Grafindo Persada, Jakarta.

Arikunto, S, (2006), Research Procedure, Revised Edition, Publisher Rineka Cipta, Jakarta.

Christin, S., (2006), Effectiveness of the Use of Audio-Visual Media on the Learning Success of SMA N 2 Kabanjahe Students, UNIMED Library, Medan.

Dahar, W.R., (2005), Learning Theories, Erlangga Publisher, Jakarta.

Holil, A., (2007), Concept Maps to Facilitate Difficult Concepts in Learning,

BlogTopSeratus, Surabaya.

Indrawati, (2000), Natural Science Learning Model, Ministry of National Education. Director General of Primary and Secondary Education, Jakarta.

Karmana, O., (2008), Biology for Class XI Semester 1 High School, Grafindo Media Pratama, Bandung.

Sudjana, (2007), Statistics Method, Tarsito, Bandung. Sudrajat, A., (2008), Learning Media, WordPress, Jakarta.

Suleiman, A., H., (1985), Audio-Visual Media for Teaching, Information and Counseling. PT.Gramedia, Jakarta.

Suryosubroto, B., (2002), Teaching and Learning in Schools, Rineka Cipta Publisher, Jakarta.

Lecturer Team, (2008), Anatomy of Human Physiology, Faculty of Mathematics and Natural Sciences, Medan State University.

Usman, H, (2006), Introduction to Statistics, Tarsito Publisher, Bandung.

Usman, U.M, (2006), Efforts to Optimize Teaching and Learning Activities, Publisher of PT Remaja Rosdakarya, Bandung.

Zubaidah, (1999), Improving Motivation for SLTP Laboraturium students' learning at Negeri State University Through Concept Maps, PTK Articles, Malang. 